\title{
Effect of Nitrogen Fertilization on the Productivity and Sensitivity of Two Sweet Sorghum Varieties to Pink Stem Borer
} (Sesamia cretica led.) Infestation

\author{
Besheit, R.S. ${ }^{1}$ and A.A. Mekdad ${ }^{2}$
}

${ }^{1}$ Sugar Crops Research Institute, Agriculture Research Center, Giza, Egypt

${ }^{2}$ Agronomy Department, Faculty of Agriculture, Fayoum University

Received on: $23 / 8 / 2016$

Accepted for publication on: 4/9/2016

\begin{abstract}
Two field experiments were conducted at Agriculture Faculty farm of Demo $\left(29^{\circ} 17 \square \quad \mathrm{N} ; 30^{\circ} 53 \square\right.$ E) El-Fayoum University, Egypt, during 2013 and 2014 to study the effect of three nitrogen rates, i.e. 80,100 and $120 \mathrm{~kg} \mathrm{~N} / \mathrm{fed}$. on the damage cause by pink stem borer infestation [Sesamia cretica Lederer (Lepidoptera: Noctuidae)] under natural infestation, on stem characteristics, quality and yield traits. In addition to theoretical ethanol production of two sweet sorghum varieties (Brandes and Honey).

Data obtained revealed that: Brandes variety is more tolerant to pink stem borer attack which recorded less damage sings measured in this study by many damage expressions. Moreover, Brandes exhibited better productivity traits (stalk, juice, syrup, grain, forage and ethanol yields) as well as quality traits (TSS, sucrose, reducing sugars, Total fermentable sugars and purity).

The results also showed that application of the highest nitrogen rate $(120 \mathrm{~kg}$ $\mathrm{N} /$ fed.) increased all borer infestation features, productivity and quality traits.

The interaction between both variables markedly affected most studied traits, but in general, Brandes variety fertilized by the highest $\mathrm{N}$ rate exhibited the higher productivity and quality traits and the lower damage signs or to some extend characterized as moderate tolerance to pink borer infestation.
\end{abstract}

Keywords: Sweet Sorghum, Nitrogen fertilizer, Sesamia cretica infestation, Juice quality, Stalk yield

\section{Introduction}

Sweet sorghum [Sorghum bicolor (L.) Moench, Poaceae] is superior to sugarcane and corn in terms of production of food calories per unit area, meantime, the cost to cultivate sweet sorghum can be as little as three times lower than that of sugarcane (Audilakshmi et al., 2010 and Xin and Wang, 2011). Further, sweet sorghum has a lower water require, drought resistant, rapid growth rate, short duration, early maturity, high energy values and wide adaptability. Moreover, sweet sorghum is a good source for starch (grain), syrup, forage, ethanol (bio-fuel) production, paper making and some varieties could used for refining sugar production (Allam et al., 2001; Almodares et al., 2009 and Aman, Salma, 2010).

Sorghum attacked by nearly 150 insect species leading to serious damage. Lepidoptera stem borer, Sesamia cretica Lederer (Lepidoptera: Noctuidae) is considered the key pest attack sorghum and it is difficult to control largely because of the nocturne habits of the adult moths and cryptic feeding behavior of the larvae which reside inside the plant stem (Ranjekar et al., 2003 and Marulasiddesha et al., 2007). The insect greatly and negatively affected stalks yield, 
grain, forage yields, juice quality, in addition to ethanol production, further, in seedlings stage the larvae migrate after hatching at the top of the plant to feed cause the dead heart (Abou Dooh, 1988;Yakoub, 2005 and Mailafiya and Degri, 2012).

Great attention have been reported by many workers to the importance of sorghum varieties and nitrogen element effect on sorghum quantity and quality traits such as Almodares and Mostafafi (2006); Marulasiddesha et al. (2007); Almodares et al.(2010); Djanaguiraman and Ramesh (2013); El-Rawy et al. (2013); Djodda et al. (2013); Abou-Amer and Kewan (2014) and El-Geddawy, et al. (2014).

This work is aimed to study the effect of nitrogen fertilization on damage cause by pink stem borer (Sesamia cretica) infestation under natural infestation on stem characteristics, juice quality, yield traits and theoretical ethanol production of two sweet sorghum varieties under ElFayoum Governorate conditions.

\section{Materials and Methods}

Field experiment was conducted at Agriculture Faculty farm of Demo $\left(29^{\circ} 170\right.$ N, 30 53] E), Fayoum University, Egypt, during 2013 and 2014 to study the effect of three nitrogen rates, i.e. 80,100 and $120 \mathrm{~kg} \mathrm{~N} / \mathrm{fed}$. on borer infestation features under natural infestation, plant characteristics, quality and yield traits of two sweet sorghum varieties(Brandes and Honey). The experiment treatments were laid out in Randomized Complete Blocks Design (RCBD) using split plot design with three replicates. Sweet sorghum varieties occupied the main plots, while, nitrogen fertilizer rates were randomly distributed in the sub-plots. Each experimental basic unit included 5 ridges, $70 \mathrm{~cm}$ apart and $6 \mathrm{~m}$ long, represented an area of $21 \mathrm{~m}^{2}(1 / 200 \mathrm{fed})$.

Sorghum grains were sown on May $9^{\text {th }}$ and $11^{\text {th }}$ in the first and second seasons, respectively. Seedlings were thinned at two plants/hill after 21 days from planting. Nitrogen was applied as urea $(46.5 \% \mathrm{~N})$ in three equal doses, one third before the first irrigation after thinning directly and the second and third ones was after 35 and 50 days after planting. Further, calcium super phosphate $(15.5 \%$ $\mathrm{P}_{2} \mathrm{O}_{5}$ ) at the rate of $100 \mathrm{~kg} / \mathrm{fed}$. was applied during land preparation. All other cultural practices were maintained at level to assure optimum growth and production and no insecticides were applied for pest control throughout the whole seasons. Soil physical and chemical properties of the experimental site were determined according to Wilde et al. (1985) as shown in Table (1).

Harvest was carried out at dough to ripe stage in both seasons from 105 to 130 days from sowing. Random sample of fifteen plants from each sub-plot was taken from the three guarded rows to determine all infestation and productivity parameters as follows:

\section{A- Borer infestation traits:}

- Dead heart percentage was recorded and calculated after 21 days from sowing (after thinning).

- Infested stalks (incidence infestation), infested joints (intensity infestation) percentages, no. of holes/15 plants (HP), no. holes/ 100 joins (HJ), and no. of larvae /15 plants. 
Table 1. Physical and chemical properties of the experimental soil in the two growing summer seasons 2013 and 2014.

\begin{tabular}{|c|c|c|c|c|}
\hline \multicolumn{3}{|c|}{ Season } & 2013 & 2014 \\
\hline \multicolumn{3}{|c|}{ Sand\% } & 66.5 & 76.1 \\
\hline \multicolumn{3}{|c|}{ Silt\% } & 12.4 & 10.8 \\
\hline \multicolumn{3}{|c|}{ Clay\% } & 21.1 & 13.1 \\
\hline \multicolumn{3}{|c|}{ Soil texture class } & Sandy clay Loam & Sandy Loam \\
\hline \multicolumn{3}{|c|}{$\mathrm{CaCO3} \%$} & 7.1 & 5.2 \\
\hline \multirow{3}{*}{ Cations } & \multirow{7}{*}{ Meq/L } & $\mathbf{N a}$ & 69.8 & 56.7 \\
\hline & & $\mathbf{K}$ & 2.82 & 1.40 \\
\hline & & Mg & 25.0 & 11.0 \\
\hline \multirow{4}{*}{ Anions } & & SO4 & 28.6 & 33.4 \\
\hline & & $\mathbf{C L}$ & 92.4 & 66.5 \\
\hline & & $\mathrm{HCO3}$ & 7.5 & 10.0 \\
\hline & & $\mathrm{CO3}$ & - & - \\
\hline \multicolumn{3}{|c|}{ Organic Matter \% } & 1.47 & 0.70 \\
\hline \multicolumn{3}{|c|}{ ECe ds/m at $25 \mathrm{C}^{0}$} & 5.89 & 5.33 \\
\hline \multicolumn{3}{|c|}{ pH at $25 \mathrm{C}^{0}$} & 7.63 & 7.87 \\
\hline \multirow{6}{*}{\multicolumn{2}{|c|}{ Micronutrients (ppm) }} & $\mathbf{F e}$ & 6.86 & 4.29 \\
\hline & & Mn & 4.21 & 3.57 \\
\hline & & $\mathbf{C u}$ & 1.46 & 0.69 \\
\hline & & Zn & 1.10 & 0.29 \\
\hline & & $\mathbf{P}$ & 71.2 & 15.0 \\
\hline & & $\mathbf{K}$ & 294.6 & 228.4 \\
\hline
\end{tabular}

-No. of leaf / plant and infested leaf percentage.

-Infested stalk length and stalk length reduction percentage.

-Tunnel length / plant and tunnel length/ stalk percentage.

\section{B- Productivity and quality traits:}

-Stalk length (cm), Stalk diameter $(\mathrm{cm})$, stalk weight $(\mathrm{g})$ and stripped stalk yield (ton/fed.).

-Grain and forage yield (ton/fed.).

Stripped stalk samples was immediately crushed through 3 roller lab mill, the raw juice was filtered and used to determine the following traits:

- Juice extraction percentage and juice yield (T/fed.).

- Syrup extraction percentage and syrup yield $(\mathrm{kg} / \mathrm{fed}$.).
- Total fermentable sugars \% (sucrose + reducing sugars) and theoretical ethanol yield $(\mathrm{EtOH})$ Liter /fed. [Which calculated according to Smith and Buxton (1993)].

- Total Soluble Solids (TSS or Brix), Sucrose \% (Pol), Reducing Sugars and Purity percentages in the extracted juice from stalks were determined according to the methods of Meade and Chen (1977).

Percentage data was transformed by Arc-sin units before statistical analysis. Statistical analysis according to the technique of analysis of variance (ANOVA) as published by Gomez and Gomez (1984), using MSTAT statistical package (MSTATC). Least Significant Differences (LSD) method was used to test the 
differences between means at 5\% level of probability.

\section{Results and Discussion \\ Borer damage expressions:}

The pink stem borer, Sesamia cretica Led. (Lepidoptera: Noctuidae) is considered the main destructive insect pest attack Sorghum genus and cause great damage from germination up to harvest in both leaf and stalks (Mathieu et al., 2006 and Djodda et al., 2013). This damage is measure by many constant parameters expressed as dead heart $(\mathrm{DH} \%)$, infested bored stalk percentage (incidence infestation), infested bored joints percentage (intensity infestation), Number of holes/15 plants (HP) and Number of holes/ 100 joints (HJ). These parameters will discussion for two sweet sorghum varieties (Brandes and Honey), nitrogen fertilizer (80, 100 and $120 \mathrm{~kg} \mathrm{~N} / \mathrm{fed}$.) and their interaction as follows:-

Results exhibited in Table 2 show that Brandes variety recorded less damage measured by the five damage expressions than Honey variety in both seasons but these differences were inconsistent with regard to its significance degree as cleared in Table (2). The differences between the two sorghum varieties may be firstly due to genetic causes as mentioned by Galal et al. (2002), secondly, Mailafiya and Degri (2012) stated that incidence of Lepidoptera stem borer depends on varieties, culture techniques and climatic factors such as temperature and relative humidity. Further, the differences between sorghum varieties were reflected negatively on productivity and quality traits as discussed later. In this connection numerous reported indi- cated that Sesamia cretica is capable of causing economic losses, meantime, sorghum genotypes differed greatly with respect to all damage types (Marulasiddesha et al., 2007; Djodda et al., 2013; El-Rawy et al., 2013 and Salman et al., 2014).

With regard to nitrogen effect, data illustrated in Table 2 that focus increasing nitrogen dressing up to $120 \mathrm{~kg} \mathrm{~N} /$ fed. gradually and significantly increased the five infestation parameters expressed as infested stalk $\%$, infested joints $\%$, no. of holes $/ 15$ stalk and no. of holes/100 joints in both seasons, except $\mathrm{DH} \%$ criteria, where, it was insignificantly affected by nitrogen fertilizer. These results may be due to that the infested by this insect appeared early in seedlings stage and before nitrogen application. Further, such effect on the other damage types may be due to that higher nitrogen level over $80 \mathrm{~kg} \mathrm{~N} / \mathrm{fed}$. stimulates initiation of new leaf detect later, increase plant moisture and decreased fiber contents which make the plant easy to attack by the insect. These findings are in harmony with those of Elwan et al. (2008); AbouAmer and Kewan (2014); Keeping et al. (2014); Salman et al. (2014); Tanzubil (2014) and Van Weelden et al. (2015) who reported that sorghum receiving high nitrogen doses is more susceptible to stem borer attack and suffered heavier losses expressed by the five damage types.

The interaction between both variables was significantly affected the five damage parameters except $\mathrm{DH} \%$ trait which gave a vise versa trend (Table 2). Meantime, the highest damage was of honey variety under $120 \mathrm{~kg} \mathrm{~N} / \mathrm{fed}$. 
Table 2. Effect of nitrogen fertilization on pink stem borer infestation parameters of two sweet sorghum varieties in 2013 and 2014 seasons.

\begin{tabular}{|c|c|c|c|c|c|c|c|c|c|c|c|c|}
\hline \multirow{2}{*}{$\begin{array}{l}\text { Treatments } \\
\text { Seasons } \\
\end{array}$} & \multicolumn{2}{|c|}{$\begin{array}{l}\text { Dead heart } \\
\text { (DH\%) }\end{array}$} & \multicolumn{2}{|c|}{ Infested stalks\% } & \multicolumn{2}{|c|}{ Infested joints\% } & \multicolumn{2}{|c|}{ No. of Larvae/15plants } & \multicolumn{2}{|c|}{$\begin{array}{c}\text { No. of } \\
\text { holes/ } 15 \text { plants }(\mathrm{HP}) \\
\end{array}$} & \multicolumn{2}{|c|}{$\begin{array}{c}\text { No. of } \\
\text { holes/ } 100 \text { joints }(\mathrm{HJ})\end{array}$} \\
\hline & 2013 & 2014 & 2013 & 2014 & 2013 & 2014 & 2013 & 2014 & 2013 & 2014 & 2013 & 2014 \\
\hline \multicolumn{13}{|l|}{ Varieties (V) } \\
\hline Brandes (V1) & 5.00 & 6.30 & 21.82 & 25.70 & 2.85 & 6.40 & 3.00 & 2.33 & 5.81 & 6.54 & 10.46 & 5.36 \\
\hline Honey (V2) & 7.50 & 8.15 & 22.78 & 29.08 & 4.84 & 7.36 & 3.33 & 4.00 & 7.13 & 8.80 & 13.02 & 9.65 \\
\hline F test (LSD 0.05) & $*(0.88)$ & $* *(1.05)$ & N.S & $* *(1.90)$ & $* *(1.19)$ & N.S & N.S & $* *(0.83)$ & N.S & $*(1.91)$ & $* *(0.96)$ & $* *(0.51)$ \\
\hline \multicolumn{13}{|l|}{ Nitrogen rates $(\mathrm{N})$} \\
\hline 80 kg N/ Fed (N1) & 5.00 & 6.39 & 20.78 & 24.72 & 2.49 & 5.22 & 2.67 & 2.00 & 3.83 & 5.70 & 7.10 & 4.68 \\
\hline 100 kg N/ Fed (N2) & 6.67 & 7.78 & 20.56 & 27.22 & 3.44 & 7.09 & 3.33 & 3.33 & 6.77 & 8.48 & 11.58 & 9.02 \\
\hline 120 kg N/ Fed (N3) & 7.09 & 7.50 & 25.56 & 30.22 & 5.61 & 8.35 & 3.50 & 4.17 & 8.82 & 8.83 & 16.53 & 8.83 \\
\hline LSD 0.05 & N.S & N.S & 1.29 & 2.30 & 1.22 & 0.84 & N.S & 1.02 & 1.02 & 2.30 & 0.75 & 0.47 \\
\hline \multicolumn{13}{|l|}{ Interaction $(\mathrm{V} \times \mathbf{N})$} \\
\hline $\mathrm{V} 1 \times \mathrm{N} 1$ & 4.17 & 5.83 & 21.00 & 22.22 & 1.47 & 4.97 & 2.33 & 1.67 & 2.43 & 4.90 & 6.97 & 3.63 \\
\hline $\mathrm{V} 1 \mathrm{x}$ N2 & 5.83 & 6.39 & 20.00 & 23.33 & 2.59 & 5.61 & 3.00 & 2.33 & 6.67 & 6.77 & 8.00 & 5.73 \\
\hline $\mathrm{V} 1 \times \mathrm{N} 3$ & 5.01 & 6.67 & 24.45 & 31.56 & 4.49 & 8.63 & 3.67 & 3.00 & 8.33 & 7.97 & 16.40 & 6.73 \\
\hline $\mathrm{V} 2 \times \mathrm{N} 1$ & 5.84 & 6.95 & 20.56 & 27.22 & 3.51 & 5.46 & 3.00 & 2.33 & 5.23 & 6.50 & 7.23 & 5.73 \\
\hline $\mathrm{V} 2 \times \mathrm{N} 2$ & 7.50 & 9.16 & 21.11 & 31.11 & 4.29 & 8.56 & 3.67 & 4.33 & 6.87 & 10.20 & 15.17 & 12.30 \\
\hline $\mathrm{V} 2 \times \mathrm{N} 3$ & 9.17 & 8.33 & 26.67 & 28.89 & 6.73 & 8.06 & 3.33 & 5.33 & 9.30 & 9.70 & 16.67 & 10.93 \\
\hline Mean & 6.25 & 7.22 & 22.30 & 27.39 & 3.85 & 6.88 & 3.17 & 3.17 & 6.47 & 7.67 & 11.74 & 7.51 \\
\hline LSD 0.05 & N.S & N.S & 2.40 & 3.05 & 1.73 & 1.19 & N.S & 1.43 & 0.81 & 3.05 & 1.06 & 0.66 \\
\hline
\end{tabular}


No. of larvae/ 15 plant:

Data presented in Table 3 shows that No. of larvae was less for Brandes variety than Honey, these differences were significantly only during 2014 season. Dealing with nitrogen application, data demonstrated that No. of larvae was increased gradually as nitrogen dressing increased to reach the highest rate (120 $\mathrm{kg} \mathrm{N} /$ fed.) for both varieties and seasons (Table 2). The high detrimental increase attained may be due that the borer infestation expressed previously by the five damage parameters, in addition to tunnel length (will discussed later) was greatly and positively associated with the No. of larvae.

Interaction between varieties and nitrogen rates was significantly affected this trait in 2014 season only and the highest No. of larvae was recorded corresponding to $120 \mathrm{~kg}$ $\mathrm{N} /$ fed. for both varieties. Van Weelden et al. (2015) found that No. of adult emergence holes per stalk increased substantially with higher rates of nitrogen.

\section{Infested leaf percentage and num- ber of leaf/plant:}

Data in Table 3 declare that infested leaf expressed as a percent from total no. of leaf/plant was more obvious for Honey variety as compared with the other variety. Nevertheless, a significant increase between the two varieties was observed only during 2013 season.

Both traits were markedly and gradually increased as nitrogen application increased to reach the highest level compensated with $120 \mathrm{~kg} \mathrm{~N} /$ fed. Dealing with the interaction, it is cleared that both variables in 2013 behave independently for No. of leaf/plant, while, infested leaf percentage was showed contrary findings. Worth to mention that the magnitude of the increase in both varieties was more higher for Honey variety in the two seasons as compared with Brandes variety (Table 3 ). The recorded results are partly in accordance with those of Abd El-Karim et al. (1999); Abd El-Raheem et al. (2010) and Aman, Salma (2010).

\section{Infested stalks length reduction:}

Data in Table 3 reveal that great and significant reduction have been detected in stalk length resulted from stalk borer infestation for both varieties and nitrogen dressing in the two seasons. Data also clear that the magnitude of reduction percentage in stalk length is more higher for Honey variety, meantime, nitrogen rate at $120 \mathrm{~kg} \mathrm{~N} /$ Fed. attained the highest and significant reduction in stalk length in both seasons. The data also show that the interaction between both factors significantly affected the reduction in stalk borer in both seasons, meanwhile, Honey and Brandes varieties under $120 \mathrm{~kg} \mathrm{~N} / \mathrm{Fed}$. recorded the highest reduction percentage (25.30 and 23.55\%) and (19.02 and 21.55) in both seasons, respectively. Abd El-Karim et al. (1999) and Abd El- Raheem et al. (2010) showed that stalk length differed markedly among sorghum varieties. Further, high nitrogen levels significantly altered sweet sorghum stalk height and girth. (Gnansounou et al., 2005 and El-Rawy et al., 2013).

Borer Tunnel length (cm) and Tunnel percentage /stalk:

Tunnel length $(\mathrm{cm})$ and tunnel $\% /$ stalk (acted from stalk length as percentage) are shown in Table 3 . 
Data clarified that both tunnel length and tunnel \%/stalk were significantly affected by Sorghum varieties and nitrogen fertilizer and their interaction (Table 3). Whereas, Honey variety exhibited the taller tunnel length and tunnel $\%$ /stalk as compared with Brandes variety. Meantime, a gradual and significant increase in tunnel length and tunnel \%/stalk as nitrogen dressing increased to reach its maximum values corresponding to $120 \mathrm{~kg}$ $\mathrm{N} /$ fed. Such effect may be due to that the increase in both traits values exhibited numerous stalk damage which reflected greatly on all productivity and quality criterion well discussed later.

The interaction between both factors had a significant effect on both traits this means that both factors were not behave independently under the condition of this experiment, whereas, the highest tunnel length and percentage of tunnel stalk were recognized for Honey and Brandes under $120 \mathrm{~kg} \mathrm{~N} / \mathrm{fed}$. recording $10.33 \mathrm{~cm}$ and $4.71 \%$ in 2013 season and $15.58 \mathrm{~cm}$ and $6.57 \%$ in 2014 season, respectively. These findings are partly in line with those reviewed by Marulasiddesha et al. (2007) and Osman et al. (2014). 
Table 3. Effect of nitrogen fertilization on pink stem borer infestation parameters of two sweet sorghum varieties in 2013 and 2014 seasons.

\begin{tabular}{|c|c|c|c|c|c|c|c|c|c|c|c|c|}
\hline \multirow{2}{*}{$\begin{array}{l}\text { Treatments } \\
\text { Seasons } \\
\end{array}$} & \multicolumn{2}{|c|}{ No. of leaf/plant } & \multicolumn{2}{|c|}{ Infested leaf \% } & \multicolumn{2}{|c|}{$\begin{array}{c}\text { Infested stalk } \\
\text { length (m) }\end{array}$} & \multicolumn{2}{|c|}{$\begin{array}{l}\text { Stalk length } \\
\text { reduction \% }\end{array}$} & \multicolumn{2}{|c|}{ Tunnel length/plant $(\mathrm{cm})$} & \multicolumn{2}{|c|}{ Tunnel \% / stalk } \\
\hline & 2013 & 2014 & 2013 & 2014 & 2013 & 2014 & 2013 & 2014 & 2013 & 2014 & 2013 & 2014 \\
\hline \multicolumn{13}{|l|}{ Varieties (V) } \\
\hline Brandes (V1) & 13.46 & 12.79 & 6.06 & 6.24 & 2.57 & 2.65 & 16.08 & 18.80 & 6.19 & 8.16 & 2.39 & 3.07 \\
\hline Honey (V2) & 14.22 & 12.48 & 8.92 & 6.14 & 2.15 & 2.28 & 21.97 & 21.45 & 8.09 & 11.21 & 3.75 & 4.87 \\
\hline F test (LSD 0.05) & $*(0.97)$ & NS & $* *(0.23)$ & NS & NS & NS & $* *(1.89)$ & $* *(1.73)$ & $*(1.78)$ & $* *(1.52)$ & $*(1.53)$ & $*(0.24)$ \\
\hline \multicolumn{13}{|l|}{ Nitrogen rates $(\mathrm{N})$} \\
\hline 80 kg N/ Fed (N1) & 12.42 & 12.08 & 5.52 & 3.07 & 2.30 & 2.39 & 15.78 & 16.98 & 4.33 & 6.52 & 1.93 & 2.79 \\
\hline 100 kg N/ Fed (N2) & 14.00 & 12.92 & 7.51 & 6.14 & 2.36 & 2.16 & 19.15 & 20.85 & 7.57 & 10.05 & 3.28 & 4.12 \\
\hline 120 kg N/ Fed (N3) & 15.11 & 12.93 & 9.44 & 9.37 & 2.42 & 2.55 & 22.16 & 22.55 & 9.52 & 12.49 & 4.01 & 5.01 \\
\hline LSD 0.05 & 1.50 & N.S & 0.55 & 0.54 & N.S & N.S & 2.05 & 1.74 & 0.84 & 1.33 & 0.26 & 0.19 \\
\hline \multicolumn{13}{|l|}{ Interaction $(\mathrm{VxN})$} \\
\hline V1 x N1 & 12.00 & 12.45 & 3.37 & 2.61 & 2.49 & 2.57 & 13.54 & 14.62 & 3.03 & 5.20 & 1.22 & 2.02 \\
\hline $\mathrm{V} 1 \times \mathrm{N} 2$ & 13.83 & 12.97 & 6.77 & 7.43 & 2.58 & 2.64 & 15.69 & 20.24 & 6.83 & 9.90 & 2.65 & 3.75 \\
\hline $\mathrm{V} 1 \times \mathrm{N} 3$ & 14.54 & 12.96 & 8.04 & 8.67 & 2.64 & 2.73 & 19.02 & 21.55 & 8.71 & 9.40 & 3.30 & 3.44 \\
\hline $\mathrm{V} 2 \times \mathrm{N} 1$ & 12.83 & 11.70 & 7.67 & 3.53 & 2.14 & 2.21 & 18.01 & 19.34 & 5.63 & 7.84 & 2.63 & 3.55 \\
\hline $\mathrm{V} 2 \times \mathrm{N} 2$ & 14.17 & 12.86 & 8.25 & 4.84 & 2.13 & 2.27 & 22.60 & 21.45 & 8.30 & 10.20 & 3.90 & 4.49 \\
\hline $\mathrm{V} 2 \times \mathrm{N} 3$ & 15.67 & 12.89 & 10.83 & 10.06 & 2.19 & 2.37 & 25.30 & 23.55 & 10.33 & 15.58 & 4.71 & 6.57 \\
\hline Mean & 13.84 & 12.64 & 7.49 & 6.19 & 2.36 & 2.47 & 19.03 & 20.13 & 7.14 & 9.69 & 3.07 & 3.97 \\
\hline LSD 0.05 & N.S & N.S & 0.78 & 0.77 & N.S & N.S & 2.65 & 1.95 & 0.99 & 1.88 & 0.63 & 0.27 \\
\hline
\end{tabular}


Stripped stalk yield and its components:

Data in Table 4 show that Brandes variety surpassed significantly stripped stalk yield and its components expressed as stalk length and individual stalk weight/g as compared with Honey variety in both seasons except stalk diameter, where, no significant differences has been detected between both varieties. The excellence of Brandes variety may be due to genetic causes acted well under the dominant environments, meantime, this variety was relatively resistant to borer damage as mentioned before (Table 2). These finding are in harmony with those reviewed by Abd El-Razek and Besheit (2008); Nour, Sara (2010); ElGeddawy, Dalia et al. (2014) and Miri and Rana (2014) who indicated a marked differences among sorghum varieties with regard to stalk yield and stalk components.

Concerning nitrogen dressing, average data Table 4 indicate a gradual and significant increase in stalk components i.e. stalk length, diameter and weight in both seasons as nitrogen application increased from $80 \mathrm{~kg}$ $\mathrm{N} /$ fed. to 100 and $120 \mathrm{~kg} \mathrm{~N} /$ fed., where, the increase in stripped stalk yield (ton/fed.) recorded $6.26 \%$ and $13.36 \%$ for 2013 season and by $4.97 \%$ and $18.22 \%$ for 2014 season, respectively, (Table 4). Such effect revealed that the soil was initially incapable of coverage the crop with its $\mathrm{N}$ requirement, because, the soil under investigation may be characterized by its low nitrogen content (Table1). Similarity, Almodares et al. (2008); Thakur et al.(2009); Ramos et al.(2012) and Mahmoud et al.
(2013) stated that increased nitrogen fertilizer significantly affected stalk dimension, stalk weight and stalk yield.

The interaction between both factors significantly affected stripped stalk yield in both seasons and stalk weight in 2013 season only, while, the other components were not significant, meantime, these traits were increased gradually as nitrogen dressing increased (Table 4).

Juice yield (Ton/fed.) and juice extraction percentage (JEP):

Brandes variety surpassed markedly juice yield and juice extraction percentage than Honey variety in both seasons (Table 4). Such effect may be due the superiority of Brandes variety with respect to stripped stalk yield. Further, Brandes characterized with relatively high resistant to the borer damage aforementioned before. (Table 2). These results are corporate by those of Mahmoud et al. (2013) and El-Geddawy, Dalia et al. (2014).

A gradual and significant increase in juice yield (T/fed.) with the increase in nitrogen level from $80 \mathrm{~kg}$ $\mathrm{N} /$ fed. to 100 or $120 \mathrm{~kg} \mathrm{~N} /$ fed. in both seasons. This increase is a reflection of the same trend of stripped stalk yield and JEP.

Interaction between both variables significantly and positively affected JEP in the two growing seasons and juice yield in 2014 season, whereas, Brandes variety under 120 $\mathrm{kg} \mathrm{N} /$ fed recorded the highest mean values of JEP (39.57\% and 39.79\%) and juice yield (14.55 and 15.60 $\mathrm{T} /$ fed.) in the $1^{\text {st }}$ and $2^{\text {nd }}$ seasons, respectively. These findings are in harmony with those of Abd El-Razek 
Table 4. Effect of nitrogen fertilization on yield and juice quality traits of two sweet sorghum varieties in 2013 and 2014 seasons.

\begin{tabular}{|c|c|c|c|c|c|c|c|c|c|c|c|c|c|c|c|c|c|c|}
\hline \multirow{2}{*}{$\begin{array}{l}\text { Treatments } \\
\text { Seasons }\end{array}$} & \multicolumn{2}{|c|}{ Stalk length (m) } & \multicolumn{2}{|c|}{$\begin{array}{c}\text { Stalk } \\
\text { diameter }(\mathrm{cm})\end{array}$} & \multicolumn{2}{|c|}{$\begin{array}{c}\text { Stalk weight } \\
\text { (g) }\end{array}$} & \multicolumn{2}{|c|}{$\begin{array}{l}\text { Stripped stalk } \\
\text { weight(Ton/fed) }\end{array}$} & \multicolumn{2}{|c|}{$\begin{array}{c}\text { Juice extraction } \\
\% \text { (JEP) }\end{array}$} & \multicolumn{2}{|c|}{$\begin{array}{c}\text { Juice yield } \\
\text { (ton/fed) }\end{array}$} & \multicolumn{2}{|c|}{ SEP } & \multicolumn{2}{|c|}{$\begin{array}{l}\text { Syrup yield } \\
\text { (kg/fed) }\end{array}$} & \multicolumn{2}{|c|}{ TFS\% } \\
\hline & 2013 & 2014 & 2013 & 2014 & 2013 & 2014 & 2013 & 2014 & 2013 & 2014 & 2013 & 2014 & 2013 & 2014 & 2013 & 2014 & 2013 & 2014 \\
\hline \multicolumn{19}{|l|}{ Varieties } \\
\hline Brandes (V1) & 07 & 3.27 & 2.90 & 3.11 & 997.57 & 1040.49 & 33.83 & 34.12 & 38.76 & 39.00 & 13.13 & 13.33 & 7.49 & 8.32 & 954 & 1027 & 12.15 & 13.19 \\
\hline Honey (V2) & 2.76 & 2.91 & 2.44 & 2.58 & 734.72 & \begin{tabular}{|l|l|}
787.57 \\
\end{tabular} & 26.77 & 28.79 & 37.89 & 38.12 & 10.14 & 10.98 & 7.32 & \begin{tabular}{|l|}
7.84 \\
\end{tabular} & 766 & 911 & 12.73 & 13.43 \\
\hline F test (LSD 0.05) & $*(0.26)$ & $*(0.36)$ & NS & NS & $*(115)$ & $* *(112)$ & $*(6.07)$ & $* *(4.15)$ & $*(0.78)$ & $*(0.68)$ & $*(1.98)$ & $* *(0.64)$ & NS & $*(0.30)$ & $*(161)$ & $*(98)$ & $*(0.47)$ & $*(0.06)$ \\
\hline \multicolumn{19}{|l|}{ Nitrogen rates } \\
\hline $80 \mathrm{~kg} \mathrm{~N} / \mathrm{Fed}(\mathrm{N} 1)$ & 75 & 2.88 & 2.48 & 2.70 & 770.59 & 814.39 & 28.44 & 29.20 & 37.64 & 37.87 & 10.72 & 11.06 & 7.69 & 8.54 & 837 & 926 & 11.56 & 12.27 \\
\hline $100 \mathrm{~kg} \mathrm{~N} /$ Fed (N2) & 2.91 & 3.10 & 2.65 & 2.80 & 854.81 & 917.50 & 30.22 & 30.65 & 38.24 & 38.55 & 11.58 & 11.83 & 7.66 & 8.01 & 880 & 944 & 12.06 & 13.61 \\
\hline $120 \mathrm{~kg} \mathrm{~N} / \mathrm{Fed}(\mathrm{N} 3)$ & 3.09 & 3.29 & 2.89 & 3.04 & 973.34 & 1010.20 & 32.24 & 34.52 & 39.10 & 39.27 & 12.63 & 13.58 & 6.86 & 7.71 & 863 & 1038 & 13.70 & 14.05 \\
\hline LSD 0.05 & 0.11 & 0.10 & 0.08 & 0.10 & 43.42 & N.S & 1.11 & 1.68 & 0.18 & 0.33 & 1.01 & 0.39 & N.S & 0.32 & N.S & 54 & 0.52 & 0.17 \\
\hline \multicolumn{19}{|l|}{ Interaction VxN } \\
\hline V1 x N1 & 2.88 & 3.01 & 2.71 & 2.99 & 888.09 & 929.76 & 30.94 & 30.51 & 37.90 & 38.06 & 11.73 & 11.61 & 7.51 & 8.66 & 922 & 942 & 10.87 & 12.22 \\
\hline V1 x N2 & 3.06 & 3.31 & 2.88 & 3.05 & 966.64 & 1029.52 & 33.80 & 32.66 & 38.80 & 39.15 & 13.11 & 12.79 & 8.01 & 8.23 & 956 & 995 & 11.70 & 13.96 \\
\hline V1 x N3 & 3.26 & 3.48 & 3.12 & 3.28 & 1137.98 & 1162.18 & 36.77 & 39.20 & 39.57 & 39.79 & 14.55 & 15.60 & 6.94 & \begin{tabular}{|l|}
8.07 \\
\end{tabular} & 983 & 1145 & 13.87 & 13.39 \\
\hline $\mathrm{V} 2 \times \mathrm{N} 1$ & 2.61 & 2.74 & 2.25 & 2.41 & 653.10 & \begin{tabular}{|l|}
699.01 \\
\end{tabular} & 25.95 & 27.89 & 37.38 & 37.68 & 9.70 & 10.51 & 7.86 & 8.41 & 751 & 909 & 12.25 & 12.51 \\
\hline $\mathrm{V} 2 \times \mathrm{N} 2$ & 2.75 & 2.89 & 2.43 & 2.55 & 742.97 & 805.48 & 26.65 & 28.63 & 37.68 & 37.94 & 10.04 & 10.86 & 7.31 & \begin{tabular}{|l|}
7.78 \\
\end{tabular} & 804 & 894 & 12.42 & 13.26 \\
\hline $\mathrm{V} 2 \times \mathrm{N} 3$ & 2.93 & 3.10 & 2.65 & 2.79 & 808.69 & 658.22 & 27.72 & 29.84 & 38.63 & 38.74 & 10.71 & 11.56 & 6.78 & \begin{tabular}{|l|}
7.34 \\
\end{tabular} & 742 & 931 & 13.53 & 14.71 \\
\hline Mean & 2.92 & 3.00 & 2.67 & 2.85 & 866.26 & \begin{tabular}{|l|}
914.03 \\
\end{tabular} & 30.30 & 31.46 & 38.33 & 38.56 & 11.64 & 12.16 & 7.40 & 8.08 & 860 & 969 & 12.61 & 13.34 \\
\hline LSD 0.05 & N.S & N.S & N.S & N.S & 61.40 & N.S & 1.56 & 2.38 & 0.26 & 0.47 & N.S & 0.56 & N.S & N.S & N.S & 77 & 0.74 & 0.38 \\
\hline
\end{tabular}


and Besheit (2008) and Miri and Rana (2014).

\section{Syrup yield (kg/fed.) and Syrup ex- traction percentage (SEP):}

Data in Table 4 indicated that syrup yield and its extraction\% were significantly affected by sorghum varieties. Brandes variety better than Honey in syrup yield and SEP in 2014 season only. These results are depending upon juice yield and syrup process efficiently. Similar findings are reviewed by Nour, Sara (2010); El-Geddawy, Dalia et al. (2014) and Miri and Rana (2014).

A gradual and substantial increase in syrup yield as nitrogen dressing increased in 2014 season, while, these trend in 2013 season was insignificant (Table 4). On the other hand, SEP decreased significantly during 2014 season only as nitrogen application increased. Such effect may be due to the increase in stalk moisture content and high loss of moisture during water evaporation in syrup manufacture. Pronounced effect of nitrogen fertilizer had been according recently by Thakur et al. (2009); Ramos et al. (2012) and Mahmoud et al. (2013).

The interaction between sorghum varieties and nitrogen fertilizer exhibited non significant effect on syrup yield and SEP in both seasons except syrup yield in 2014 season. Further, Brandes variety and $120 \mathrm{~kg}$ $\mathrm{N} /$ fed. exhibited the highest syrup yield and SEP value in both seasons.

Ethanol yield [Liter/fed. (ETOH)] and total fermentable sugars (TFS)\%:

Nowadays, ethanol or bioethanol or bio-fuel is very important due to its utilization as natural source of free octane fuel beside its employment in variety purposes. Therefore, use of agricultural resources rich and available carbohydrates could be easy fermented to ethanol production. Nevertheless, sweet sorghum juice, bagasse and grain could be used in implement this goal. In this connection, data Table (5) illustrated that estimate ethanol production ( $\mathrm{L} / \mathrm{fed}$.) from sorghum juice was significantly higher for Brandes variety than of Honey variety.

This superiority may be due to genetically causes and/or high juice yield, otherwise, total fermentable sugar had a vice versa trends with respect to the used varieties (Table 4). These results are in agreement with those obtained by Abd El-Razek and Besheit (2008).

Dealing with nitrogen dressing, data in Tables (4 and 5) indicated a gradual increase in both traits as nitrogen rate increase to reach its maximum value corresponding to $120 \mathrm{~kg}$ $\mathrm{N} /$ fed. Such effect may be due to the same effect of nitrogen rate on sucrose, reducing sugars will be discussion later and juice yield as discussed before. These results are in line with those of Byrt et al. (2011) and Miri and Rana (2014).

The interaction between both factors significantly affected both traits, thereafter, the highest fermentable sugars and ethanol alcohol production were obtained by the two tested varieties fertilizer by $120 \mathrm{~kg}$ $\mathrm{N} /$ fed. (Tables 4 and 5).

\section{Grain yield (ton/fed):}

Data given in Table 5 clear that sorghum varieties, nitrogen fertilizers and their interaction significantly affected grain yield. Further, Brandes 
Table 5. Effect of nitrogen fertilization on yield and juice quality traits of two sweet sorghum varieties in 2013 and 2014 seasons.

\begin{tabular}{|c|c|c|c|c|c|c|c|c|c|c|c|c|c|c|c|c|}
\hline \multirow{2}{*}{$\begin{array}{l}\text { Treatments } \\
\text { Seasons }\end{array}$} & \multicolumn{2}{|c|}{$\begin{array}{c}\text { EtoH } \\
\text { (L/fed) }\end{array}$} & \multicolumn{2}{|c|}{$\begin{array}{c}\text { Weight of } 1000 \text { grain } \\
\text { (g) }\end{array}$} & \multicolumn{2}{|c|}{$\begin{array}{c}\text { Grain yield } \\
\text { (Ton/fed) }\end{array}$} & \multicolumn{2}{|c|}{$\begin{array}{c}\text { Forage yield } \\
\text { (Ton/fed) }\end{array}$} & \multicolumn{2}{|c|}{$\begin{array}{c}\text { Total Soluble Solids } \\
\text { (Brix) } \%\end{array}$} & \multicolumn{2}{|c|}{$\begin{array}{c}\text { Pol \% } \\
\text { (Sucrose\%) }\end{array}$} & \multicolumn{2}{|c|}{$\begin{array}{l}\text { Reducing } \\
\text { sugars } \\
(\mathbf{R S}) \%\end{array}$} & \multicolumn{2}{|c|}{$\begin{array}{c}\text { Purity } \\
\% \%\end{array}$} \\
\hline & 2013 & 2014 & 2013 & 2014 & 2013 & 2014 & 2013 & 2014 & 2013 & 2014 & 2013 & 2014 & 2013 & 2014 & 2013 & 2014 \\
\hline \multicolumn{17}{|l|}{ Varieties } \\
\hline Brandes (V1) & 879 & 939 & 36.06 & 38.06 & 1.53 & 1.59 & 4.22 & 4.34 & 16.52 & 16.86 & 8.54 & 8.37 & 3.94 & 4.82 & 51.62 & 49.58 \\
\hline Honey (V2) & 690 & 769 & 32.78 & 34.18 & 1.19 & 1.25 & 3.36 & 3.54 & 15.99 & 16.24 & 7.83 & 8.02 & 4.87 & 5.47 & 48.90 & 49.36 \\
\hline F test (LSD 0.05) & $*(68)$ & $* *(45)$ & NS & $* *(3.28)$ & $*(0.29)$ & $*(0.25)$ & **(0.13) & $* *(0.11)$ & $*(0.40)$ & $*(0.61)$ & $* *(0.31)$ & NS & $* *(0.17)$ & $*(0.63)$ & $*(1.43$ & NS \\
\hline \multicolumn{17}{|l|}{ Nitrogen rates } \\
\hline $80 \mathrm{~kg} \mathrm{~N} / \mathrm{Fed}(\mathrm{N} 1)$ & 656 & 728 & 33.36 & 34.50 & 1.20 & 1.25 & 3.46 & 3.65 & 15.72 & 15.93 & 7.55 & 7.70 & 4.01 & 4.67 & 48.04 & 48.35 \\
\hline $100 \mathrm{~kg}$ N/ Fed (N2) & 775 & 859 & 34.04 & 35.70 & 1.34 & 1.43 & 3.78 & 3.98 & 16.34 & 16.82 & 8.28 & 8.43 & 4.23 & 5.18 & 50.62 & 50.08 \\
\hline $120 \mathrm{~kg}$ N/ Fed (N3) & 922 & 976 & 35.86 & 38.12 & 1.53 & 1.59 & 4.13 & 4.19 & 16.71 & 16.90 & 8.71 & 8.45 & 4.99 & 5.60 & 52.13 & 50.00 \\
\hline LSD 0.05 & 76 & 35 & 0.96 & 1.79 & 0.07 & 0.08 & 0.17 & 0.20 & 0.28 & 0.30 & 0.30 & N.S & 0.33 & 0.35 & 1.26 & N.S \\
\hline \multicolumn{17}{|l|}{ Interaction $\mathrm{VxN}$} \\
\hline $\mathrm{V} 1 \times \mathrm{N} 1$ & 679 & 755 & 34.71 & 36.10 & 1.31 & 1.36 & 3.82 & 4.02 & 16.16 & 16.37 & 7.73 & 7.84 & 3.14 & 4.38 & 47.81 & 47.89 \\
\hline $\mathrm{V} 1 \times \mathrm{N} 2$ & 886 & 951 & 35.24 & 37.21 & 1.51 & 1.59 & 4.21 & 4.39 & 16.60 & 17.12 & 8.78 & 8.98 & 3.92 & 4.98 & 52.91 & 52.44 \\
\hline $\mathrm{V} 1 \times \mathrm{N} 3$ & 1071 & 1112 & 38.24 & 40.78 & 1.76 & 1.81 & 4.63 & 4.60 & 16.81 & 17.09 & 9.10 & 8.28 & 4.77 & 5.11 & 54.15 & 48.41 \\
\hline $\mathrm{V} 2 \times \mathrm{N} 1$ & 633 & 700 & 32.01 & 32.90 & 1.09 & 1.14 & 3.10 & 3.27 & 15.28 & 15.48 & 7.38 & 7.56 & 4.87 & 4.95 & 48.27 & 48.80 \\
\hline $\mathrm{V} 2 \times \mathrm{N} 2$ & 664 & 767 & 32.85 & 34.19 & 1.17 & 1.26 & 3.35 & 3.56 & 16.09 & 16.51 & 7.78 & 7.88 & 4.54 & 5.38 & 48.34 & 47.71 \\
\hline $\mathrm{V} 2 \times \mathrm{N} 3$ & 772 & 839 & 33.48 & 35.46 & 1.31 & 1.36 & 3.64 & 3.77 & 16.61 & 16.71 & 8.32 & 8.62 & 5.21 & 6.09 & 50.10 & 51.58 \\
\hline Mean & 784 & 854 & 34.42 & 36.11 & 1.36 & 1.42 & 3.79 & 3.94 & 16.26 & 16.55 & 8.18 & 8.19 & 4.41 & 5.15 & 50.26 & 49.47 \\
\hline LSD 0.05 & 79 & 50 & 1.36 & N.S & 0.09 & 0.12 & 0.29 & 0.37 & N.S & N.S & 0.26 & N.S & 0.46 & N.S & 1.78 & N.S \\
\hline
\end{tabular}


variety recognized the higher mean of grain yield as compared with Honey variety, meantime, as nitrogen rates increased grain yield increased to reach its maximum corresponding to $120 \mathrm{~kg} \mathrm{~N} /$ fed., data also cleared that both varieties and nitrogen rate of $120 \mathrm{~kg} \mathrm{~N} /$ fed. exhibited the highest grain yield. In this connection, Ali et al. (2006); Abou-Amer and Kewan (2014) indicated that varieties and nitrogen fertilizer greatly affected sorghum grain yield.

\section{Forage yield (ton/fed):}

The important of forage yield is due to the shortage of green feed during summer months. Nevertheless, green leaves, branches and tillers are the forage components, further, sorghum forage is characterized by high palpability for animals. In this study data Table (5) demonstrated that Brandes variety exhibited the highest and significant forage yield than Honey variety. Such effect may be due to that Honey variety showed high leaves damage by borer infestation in Table (3) which reflected markedly on forage yield. These results are in harmony with those reported by Besheit et al. (1996) and Abd El-Karim et al. (1999).

Data in Table 5 also illustrated that forage yield increased significantly as nitrogen rate increased. Such effect may be due to the positive effect of nitrogen element on all forage components. Further, the highest forage yield observed for both varieties was subtended to $120 \mathrm{~kg}$ $\mathrm{N} /$ fed. Similar findings are stated by Abou- Amer and Kewan (2014).

\section{Juice quality:}

The features of juice quality are Total Soluble Solids (TSS or Brix),
Sucrose (Pol), reducing sugars and purity percentage.

Therefore, data (Table 5) clarified that the two used varieties differed significantly with respect to all juice features except, sucrose and purity percentages during 2014 season, where, the differences were too small to reach the level of significance. Further, Brandes variety exhibited the higher brix, sucrose and purity values in both seasons. However, Honey variety recorded the higher reducing sugars. These features are greatly affected juice and syrup characteristics. The obtained results are agreement with those reported by Almodares et al. (2010) and El- Geddawy, Dalia et al. (2014).

As nitrogen increased from 80 to 100 and $120 \mathrm{~kg} \mathrm{~N} /$ fed. all quality traits were gradually and significantly increased in both seasons except, sucrose and purity in 2014 season. Interaction between both variables insignificantly affected all quality traits except sucrose, reducing sugars and purity percentage during 2013 season, where, the differences were too small to reach the level of significance. Similar findings are affirmed by many workers such as Almodares et al. (2010); Byrt et al. (2011); Mahmoud et al. (2013) and El- Geddawy, Dalia et al. (2014) revealed that nitrogen element greatly affected sorghum juice quality especially under soil nitrogen shortage.

It could be concluded that the obtained results mentioned to the successful of sowing sweet sorghum under El-Fayoum governorate as multipurpose crop characterize by high production of syrup, ethanol, grain and forage yields, and relatively 
high degree of tolerant to pink borer infestation which considered the main and destructive pest insect attack sorghum genus in this area. Further studies have been needed to test more varieties for productivity and quality, and doing a survey for other pest insects attack sorghum as preferable host.

Worth to mentioned that, sweet sorghum characterized with low sucrose, and high reducing sugars values are more suitable in fermentable industries or syrup production quality not quantity due to minimize sucrose crystallization.

\section{References}

Abd El-Karim, H.A; T.S. El-Ammari and Maria G. Beshay (1999). Evaluation of some sweet sorghum cultivars for syrup and biomass production. J.Agric. Sci. Mansoura Univ., 24 (10): 5285 - 5295.

Abd El-Raheem, A.A.; M.S.H. Ahmed and H.F. Mohamed (2010). Evaluation of some sweet sorghum genotypes to stem corn borer resistance with presence of morphological and chemical characters. J. Plant Prot. and Path., Mansoura Univ., 1 (12): 1087-1097.

Abd El-Razek, A.M., and S.Y. Besheit (2008). Potential of some sweet sorghum (Sorghum bicolor L. Moench) varieties for syrup and ethanol production in Egypt. Sugar Tech., 11: 239-245.

Abou-Amer, A. I. and K.Z. Kewan (2014). Effect of NP fertilization levels on sorghum (Sorghum bicolor L.) yield and fodder quality for animals. Alex. J. Agric. Res., 59(1):51-59.

Abu-Dooh, A.M. (1988). Relationship between sugarcane borer, Chilo agamemnon Blez. attack on incidence, intensity and loss of the sugarcane yield. Assiut J. Agric. Sci., 28(2): 9-15.

Ali, A.I.; F. Schulthess; C.K.P. Ogol and C.O. Omwega (2006). Effect of nitrogen fertilizer level on infestation of lepidopterous stem borers and yield of maize in Zanzibar. Annales de la Société Entomologique de France (N.S.), 42 (3-4): 481-486.

Audilakshmi, S.; A.K. Mall; M. Swarnalatha and N. Seetharama (2010). Inheritance of sugar concentration in stalk (brix), sucrose content, stalk and juice yield in sorghum. Biomass Bioenerg., 34: 813- 820.

Allam, S.M.; A.M. Nassar, A.M. Abo; El-Wafa and M.K. Ali (2001). Quality and processing evaluation of some sweet sorghum varieties and their potentialities for Syrup and ethanol production. J. Agric. Sci. Mansoura Univ., 26 (1): 112.

Almodares, A., and D.S.M. Mostafafi (2006). Effects of planting date and time of nitrogen application on yield and sugar content of sweet sorghum. J. Environ. Biol., 27: 601-605.

Almodares, A; M. Jafarinia and M.R. Hadi (2009). The effects of nitrogen fertilizer on chemical compositions in corn and sweet sorghum. American-Eurasian J. Agric. and Environ. Sci., 6 (4): 441-446.

Almodares, A.; M. Ranjbar and M.R. Hadi (2010). The effects of nitrogen treatments and harvesting stages on the aconitic acid, invert sugar and fiber in sweet sorghum cultivars. J. Environ. Biol., 31(6): 1001-1005.

Almodares, A.; R. Taheri; M. Chung and M. Fathi, (2008). The effect of nitrogen and potassium fertilizers on growth parameters and carbohydrate contents of sweet sorghum cultivars. J. Environ. Biol., 29: 849-852. 
Aman, Salma, M.M. (2010). Effect of nitrogen fertilization and time of harvest on chemical composition of sweet sorghum. M. Sc. Thesis, Fac. Animal Production, Khartoum Univ., El-Sudan, 33 p.

Besheit, S.Y.; A.A. Dooh; G.B. Maria and M.K. Ali (1996). Stalk and technochemical characteristics of two sweet sorghum cultivars as influenced by nitrogen fertilization. Adv. Agric. Res., 1: 36-42.

Byrt, C.S.; C.P.L. Grof and R.T. Furbank (2011). C4 plants as biofuel feedstocks: optimising biomass production and feedstock quality from a lignocellulosic perspective. J. Integra. Plant Biol. 53: 120-135.

Djanaguiraman, M. and D. Ramesh (2013). Increasing millable cane yield of sweet sorghum through altered nitrogen, population level and plant growth regulators spray. ESci J. Crop Prod., 2: 8-18.

Djodda, J.; E.N. Nukenine; P. Ngassam and H. Yougouda (2013). Degree of infestation of transplanted sorghum [Sorghum bicolor (L) Moench] by Lepidoptera stems borers and their biodiversity in Diamaré (Maroua, Cameroon). American Open J. Agric. Res., 1(1):1-7.

El-Geddawy, Dalia I.H.; N.M.M. Awad and Sahar M.I. Moustafa (2014). Lighting spot around yield and technological characteristics of some sweet sorghum varieties. Int. J. Curr. Microbiol. App. Sci., 3(4): 843-850

El-Rawy, A.M.; A.E.A.A. Mourad and A.M. EL-Kady (2013). Evaluation of some grain sorghum lines for resistance to Sesamia cretica Led. and yield potential. Egypt. J. Agric. Res., 91 (3): 977-989.

Elwan, E.A.; A.A. Abazied; L.A. Yousswf and H.E.A. Saker (2008). Effects of some agricultural prac- tices on the infestation with the lesser sugarcane borer, Chilo agamemnon Bles. in the spring plant cane and its $1^{\text {st }}$ ratoon in Upper Egypt. Egypt. J. Agric. Res., 86(5): 1747-1762.

Galal, A.A.; A.A. El-Shenawy and E.A. Amer (2002). Additive, dominance, and epistatic effects controlling resistance to Sesamia cretica led. in maize. Minufiya J. Agric. Res., Minufiya Univ., Egypt, 27: 1209-1215.

Gnansounou, E; A. Dauriat; C.W. Wyman (2005). Refining sweet sorghum to ethanol and sugar: economic trade-offs in the context of North China. Bioresource Technol., 96: 985-1002.

Gomez, K.A. and A.A. Gomez (1984). Statistical procedures for Agric. Res., 2nd Ed. John Willey and Sons, NewYork, pp.680

Keeping, M.G.; N. Miles and C. Sewpersad (2014). Silicon reduces impact of plant nitrogen in promoting stalk borer (Eldana saccharina) but not sugarcane thrips (Fulmekiola serrata) infestations in sugarcane. Frontiers in Plant Science, 5: 1-12.

Mahmoud, E.A.; B.S.H. Ramadan; M.A. Bekheet and M.A. Gomaa (2013). Effect of nitrogen fertilization and plant density on productivity and quality of sweet sorghum. American-Eurasian J. Agric. and Environ. Sci., 13 (5): 654-659.

Mailafiya, D. M. and M.M. Degri (2012). Stem borer's species composition, abundance and infestation on maize and millet in Maiduguri, Nigeria. Arch. Phytopath. and Plant Protect., 45 (11):1286-1291.

Marulasiddesha, K.N.; M. Sankar and G.K.R. Gouda (2007). Short communication. Screening of sorghum genotypes for resistance to damage caused by the stem borer Chilo 
partellus (Swinhoe). Spanish J. Agric. Res., 5(1): 79-81.

Mathieu, B.; A. Ratnadass; A. Aboubakary; J. Beyo and P. Moyal (2006). Losses caused by stem borers to transplanted sorghum crops in northern Cameroon. International Sorghum and Millets Newsletter 47: 75-77.

Meade, G.P. and J.C.P. Chen (1977). Can Sugar Handbook, 10 th edition. Wiley-Interscience, Publication, New York, pp. 405.

Miri, K. and D.S. Rana (2014). Productivity, nutrient uptake and profitability of sweet sorghum-mustard cropping system under different levels of nitrogen. American J. Agric. Sci. and Technol., 2(2): 62-73.

Nour, Sara O.M.M. (2010). Effects of nitrogen fertilizer on growth and brix value of three sweet sorghum (Sorghum bicolor L. Moench) genotypes. M.Sc.Thesis, Fac. Agric., Khartoum Univ., El-Sudan, 49 p.

Osman, M.A.M.; Y.Y. Mosleh and M.F. Mahmoud (2014). Toxicity and biochemical impacts of Spinosad on the pink corn stem borer Sesamia cretica Led. (Lepidoptera: Noctuidae). Mun. Ent. Zool., 9(1): 429-439.

Ramos, T.A.; N.L. Castanheira; M.C. Concalves; M.I. Fernandes; M.I. Januario; M.E. Lourenco; F.P. Pires and J.C. Martins (2012). Effect of combined use of brackish water on nitrogen fertilizer on biomass and sugar yield of sweet sorghum. Pedsophere, 22(6): 785794.

Ranjekar P.; P. Aparna; G. Vidya and R. Bhatnagar (2003). Genetic engineering of crop plants for insect resistance. Curr. Sci. India 84, 3-10.

Salman, A.M.A.; A.A. Abazied and A.M. Fahmy (2014). Effect of some cultural practices on the infestation level of Chilo agamemnon Bles., infesting sugarcane varieties at Luxor Governorate. Middle East J. Agric. Res., 3(3): 569575.

Smith, G.A., and D.R. Buxton (1993). Temperate zone sweet sorghum ethanol production potential. Bioresour. Technol., 43:71-75.

Tanzubil, P.B. (2014). Effect of variety and nitrogen fertilization on insect pest incidence in Sorghum in the Sudan Savanna of Ghana. J. Entomol. Zool. Stud., 2 (6): 12-15.

Thakur, N.S.; B.B. Kushwaha; N.K. Sinha and S.N. Upadhya (2009). Effect of plant density and nitrogen levels on growth, yield attributes and yields of sweet sorghum (Sorghum bicolor L.) Moench) genotypes. Indian J. of Dryland Agric. Res. and Development, 24(1): 34-38.

Van Weelden, M.T.; B.E. Wilson; J.M. Beuzelin; T.E. Reagan; M.O. Way (2015). Yield response to Mexican rice borer (Lepidoptera: Crambidae) injury in bioenergy and conventional sugarcane and sorghum. J. Econ. Entomol., 108 (5): 2296-2304.

Wilde, S.A.; R.B. Corey; J.G. Lyer and G.K. Voigt (1985). Soil and Plant Analysis for tree Culture. Oxford and IBM Publishers, New Delhi, India, 3rd ed., pp. 93-106.

Xin, Z. and M.L.Wang (2011). Sorghum as a versatile feedstock for bioenergy production. Biofuels 2: 577- 588 .

Yakoub, R.S. (2005). Relative susceptibility of some new promising sugarcane varieties to the stalk borer, Chilo agamemnon Bles. M.Sc.Thesis, Fac. Agric., Cairo Univ., Egypt, 243p. 
تاثير التسميد الاوزتى على انتاجية وحساسية صنفين من الذرة الرفيعه السكرية للاصابة

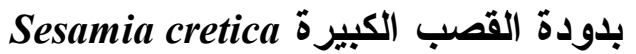

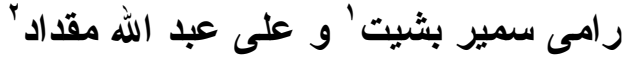

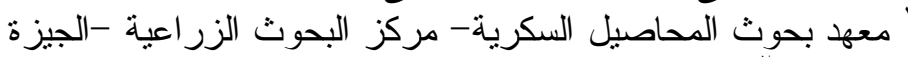

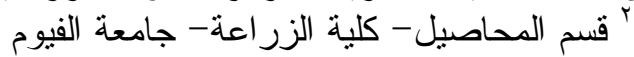

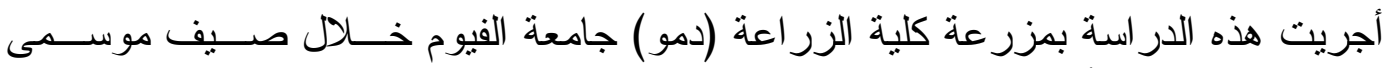

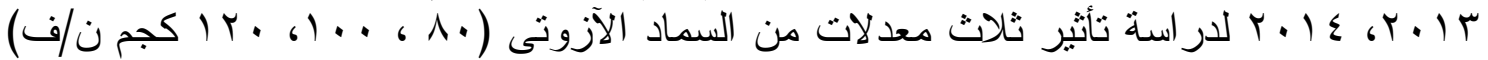

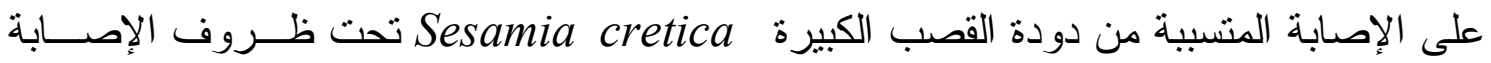

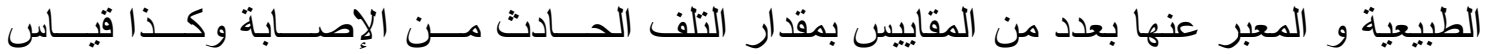

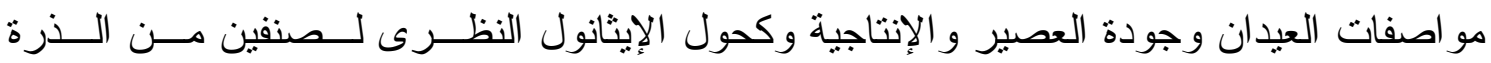

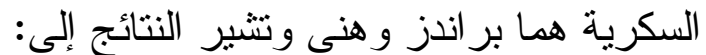

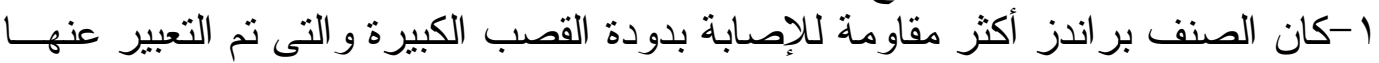

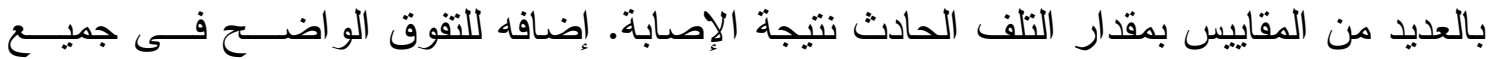

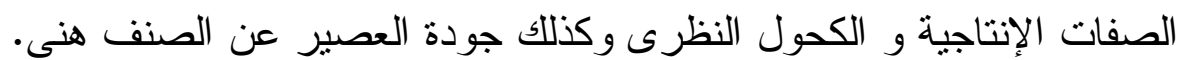

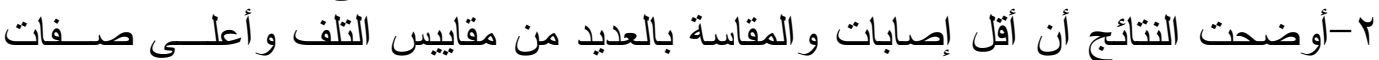

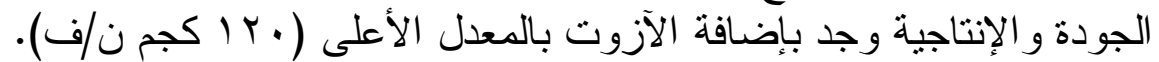

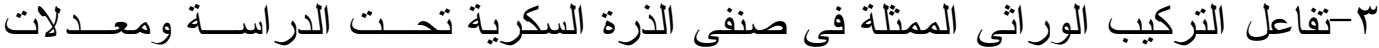
الآزوت أدى إلى تأثثر و اضح على معظم مقاييس الإصابة وكذلك الصفات الصفات الإنتاجية و الجودة.

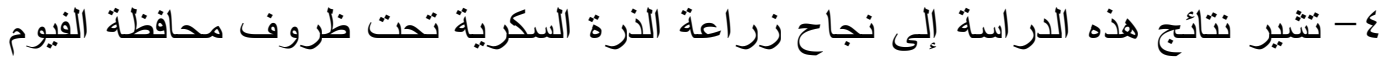

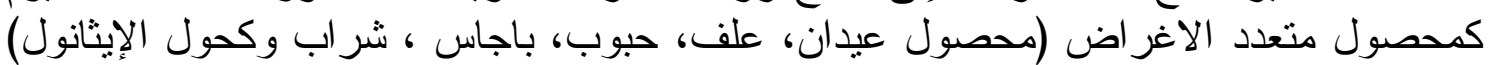

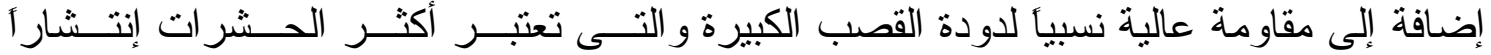

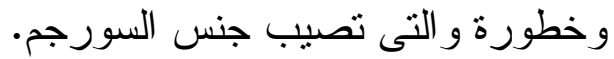

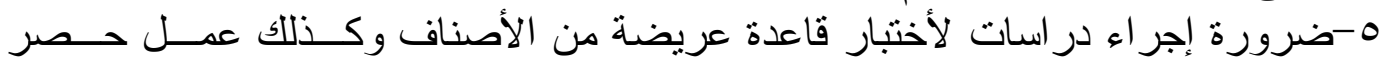

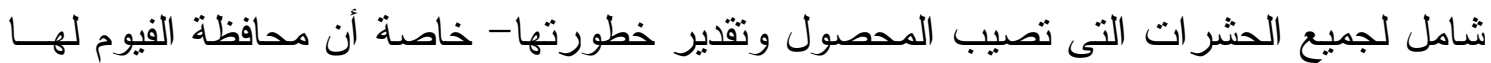
ظروف بيئية وأرضية مختلفة عن باقى المحافظات. 